\title{
Functional Interactions between Tumor and Peripheral Nerve: Changes in Excitability and Morphology of Primary Afferent Fibers in a Murine Model of Cancer Pain
}

\author{
David M. Cain, ${ }^{1}$ Paul W. Wacnik, ${ }^{2}$ Michelle Turner, ${ }^{4}$ Gwen Wendelschafer-Crabb, ${ }^{3}$ William R. Kennedy, ${ }^{3}$ \\ George L. Wilcox, ${ }^{2}$ and Donald A. Simone ${ }^{1,5}$ \\ Departments of ${ }^{1}$ Oral Science, ${ }^{2}$ Pharmacology, ${ }^{3}$ Neurology, ${ }^{4}$ Neuroscience, and ${ }^{5}$ Psychiatry, University of Minnesota, \\ Minneapolis, Minnesota 55455
}

\begin{abstract}
We used a murine model to investigate functional interactions between tumors and peripheral nerves that may contribute to pain associated with cancer. Implantation of fibrosarcoma cells in and around the calcaneus bone produced mechanical hyperalgesia of the ipsilateral paw. Electrophysiological recordings from primary afferent fibers in control and hyperalgesic mice with tumor revealed the development of spontaneous activity $(0.2-3.4 \mathrm{~Hz})$ in $34 \%$ of cutaneous C-fibers adjacent to the tumor (9-17 $d$ after implantation). C-fibers in tumor-bearing mice exhibited a mean decrease in heat threshold of $3.5 \pm 0.10^{\circ} \mathrm{C}$. We also examined innervation of the skin overlying the tumor. Epidermal nerve fibers (ENFs) were immunostained for protein gene product 9.5, imaged using confocal microscopy, and analyzed in terms of number of fibers per millimeter of epidermal length and branching (number of nodes per fiber). Diver-
\end{abstract}

gent morphological changes were linked to tumor progression. Although branching of ENFs increased significantly relative to control values, in later stages (16-24 d after implantation) of tumor growth a sharp decrease in the number of ENFs was observed. This decay of epidermal innervation of skin over the tumor coincided temporally with gradual loss of electrophysiological activity in tumor-bearing mice. The development of spontaneous activity and sensitization to heat in C-fibers and increased innervation of cutaneous structures within the first 2 weeks of tumor growth suggest activation and sensitization of a proportion of $\mathrm{C}$-fibers. The decrease in the number of ENFs observed in later stages of tumor development implicates neuropathic involvement in this model of cancer pain.

Key words: tumor; cancer pain; primary afferent fibers; epidermal nerve fibers; murine model; hyperalgesia
Cancer is often accompanied by pain that increases with metastatic infiltration and destruction. The pain is particularly difficult to treat in advanced stages of the disease and when tumors infiltrate bone or nerve. Improved treatment for cancer pain is dependent on understanding the mechanisms by which tumor growth causes pain. To investigate neurobiological mechanisms underlying cancer pain, we have used a mouse model to investigate functional interactions between tumors and peripheral nerve that may contribute to cancer-evoked pain and hyperalgesia. This model is predicated on the implantation of fibrosarcoma cells into the $\mathrm{C} 3 \mathrm{H}$ strain of mouse (Schwei et al., 1999; Honore et al., 2000a,b; Wacnik et al., 2000). Implantation of tumor-inducing cells into the intramedullary space of the mouse femur produces a bone cancer model that compares well with aspects of human bone cancer, e.g., increased osteoclast activity preceding bone destruction and hyperalgesia that is attenuated by morphine. Pathological cellular effects of metastatic bone destruction in the spinal cord include hypertrophy of astrocytes, increased internalization of the substance $\mathrm{P}$ receptor, increased expression of $\mathrm{c}$-fos

Received June 11, 2001; revised Aug. 8, 2001; accepted Aug. 31, 2001.

This work was supported by National Institutes of Health Grants CA91007 and DA11471 (D.A.S.). We thank Dr. Denis R. Clohisy and Margaret L. Ramnaraine for culturing fibrosarcoma cells for tumor induction, Dr. Mona M. Selim for help with quantification of epidermal nerve fibers, and Dr. Jim Hodges for advice on statistical analysis. We also appreciate the comments by Dr. Al Beitz and Laura Eikmeier on an earlier version of this manuscript.

Correspondence should be addressed to Donald A. Simone, Department of Oral Science, University of Minnesota, 17-252 Moos Tower, 515 Delaware Street SE, Minneapolis, MN 55455. E-mail: simon003@umn.edu.

Copyright (ㄷ) 2001 Society for Neuroscience 0270-6474/01/219367-10\$15.00/0 protein in lamina I of the spinal cord after non-noxious palpation of the bone and deep tissues in tumor-bearing mice, and increased expression of the prohyperalgesic opioid peptide dynorphin in the deep spinal laminae ipsilateral to the side of bone destruction (Schwei et al., 1999; Honore et al., 2000a,b). Because pain in human patients with bone cancer tends to increase in relation to bone destruction induced by osteoclast activity (Clohisy and Ramnaraine, 1998), inhibition of osteoclast-mediated bone resorption diminishes pain-related behaviors by halting osteoclast development and activation (Honore et al., 2000b).

In the companion paper in which a similar model was used (Wacnik et al., 2001), implantation of tumor-inducing cells in and around the calcaneus bone produced osteolysis and cutaneous mechanical and cold hyperalgesia. It was also shown that endothelin-1 (ET-1), which is known to cause nociceptive behavior and excite primary afferent fibers (Davar et al., 1998; Fareed et al., 2000), is released from the fibrosarcoma. We hypothesized that enhanced excitability would occur in C-fibers because tumors produced an increase in internalization of substance $\mathrm{P}$ receptors in spinal neurons (Schwei et al., 1999), and most of the substance $P$ released in the spinal cord is from small-caliber afferent fibers (Mantyh et al., 1995; Allen et al., 1997, 1999). In addition, growth factors (Bonetti et al., 1997; Tsujino et al., 1997) released from tumors or physical properties associated with tumors, such as compression, may result in structural modification of nerve fibers leading to abnormal activity. We reasoned that either proliferation of nerve fibers, particularly unmyelinated endings, or nerve degeneration would contribute to increased excitability. We 
therefore quantified the effects of tumor development on epidermal innervation.

\section{MATERIALS AND METHODS}

\section{Subjects}

A total of 113 adult ( $>6$ weeks old) male $\mathrm{C} 3 \mathrm{H}$ mice weighing 20-29 gm were used. Because the cell line (NCTC clone 2472) used to induce tumors in the mouse cancer pain model was derived from $\mathrm{C} 3 \mathrm{H}$ mice, this strain is optimally tumorigenic. Animals were obtained from the National Institutes of Health, housed on a $12 \mathrm{hr}$ light/dark schedule, and given ad libitum access to food and water. All animal procedures were approved by the Animal Care Committee of the University of Minnesota, and experiments were conducted according to the guidelines set forth by the International Association for the Study of Pain.

\section{Implantation techniques}

Mice were placed in an enclosed chamber and anesthetized with halothane in preparation for cell implantation. When the animal demonstrated nonresponsiveness to paw pinch, it was removed from the chamber and fitted with a facemask that continuously delivered 1-2\% halothane in an air/oxygen mixture throughout the surgery. The level of anesthesia was monitored throughout the procedure by responsiveness to paw pinch to ascertain satisfactory depth of anesthesia. Mice showing signs of permanent motor dysfunction after tumor implantation were euthanized.

NCTC clone 2472 connective tissue cells were obtained from American Type Cell Culture and maintained as described previously (Clohisy et al., 1996). The cells were grown to confluence in $75 \mathrm{~cm}^{2}$ flasks in NCTC 135 medium, $\mathrm{pH} 7.35,10 \%$ horse serum, and passed one time weekly by a 1:4-6 split ratio. Cells were prepared for implantation by first pouring off the medium and rinsing with PBS. Trypsin was then added for 5-10 min to detach cells from the flask and create a single-cell suspension. The enzymatic action was stopped with a sufficient volume of the appropriate culture medium. The cells were then counted with a hemacytometer, pelleted, resuspended, rinsed in PBS, pelleted a second time, and resuspended in PBS for implantation in a concentration of $2 \times$ $10^{5}$ cells $/ 10 \mu \mathrm{l}$.

Cells were injected unilaterally into and around the calcaneus bone in a volume of $10 \mu \mathrm{l}$. Injection required the single use of a $0.3 \mathrm{cc}$ insulin syringe, whereupon the syringe was used both to bore through the calcaneus bone (proximal to distal) and inject the cells as the needle was withdrawn. This implantation protocol was derived from a femur skeletal metastasis model that has been used to study the cellular and biochemical mechanisms mediating bone destruction at the tumor site (Clohisy et al., 1996).

\section{Behavioral studies: measurement of hyperalgesia}

To ensure that all mice with tumor used in the electrophysiological studies were hyperalgesic, withdrawal responses evoked by a von Frey monofilament ( $3.4 \mathrm{mN}$ bending force) were obtained from the hindpaw of each animal. Mice were placed on a wire mesh platform, covered with a hand-sized container, and allowed to acclimate to their surroundings for a minimum of $30 \mathrm{~min}$ before testing. The von Frey monofilament was applied to the plantar surface of the hindpaw at random locations. Withdrawal response frequency was measured from 6-10 trials. For each trial, the filament was applied at $1-5 \mathrm{sec}$ intervals. Withdrawal response frequencies were obtained for $3 \mathrm{~d}$ before tumor cell implantation and at various days after implantation. Mechanical hyperalgesia was defined as an increase in withdrawal frequency at least two SDs greater than the SD of the baseline mean. For electrophysiological study, we further restricted selection of mice with tumor to those animals that exhibited a withdrawal frequency $\geq 80 \%$ for at least 2 consecutive days.

\section{Electrophysiological studies}

Electrophysiological recording from primary afferent fibers. A total of 86 mice were used in electrophysiological experiments (control, $n=42$; mice with tumor, $n=44$ ). Of the mice with tumor, only those determined to be hyperalgesic to mechanical stimuli were used. Animals were sedated with acepromazine maleate $(20 \mathrm{mg} / \mathrm{kg}$, i.p.) and anesthetized with sodium pentobarbital (Nembutal, $48 \mathrm{mg} / \mathrm{kg}$, i.p.). Supplemental doses of sodium pentobarbital $(15 \mathrm{mg} / \mathrm{kg})$ were given as needed to maintain areflexia. Hair was removed from one hind limb and an incision was made on the dorsal aspect of the lower leg in the skin overlying the tibial nerve. After the gastrocnemius muscle was surgically removed, the skin was sutured to a metal ring (inner diameter $1.3 \mathrm{~cm}$ ) to form a basin that was filled with warm mineral oil. The tibial nerve was dissected from connective tissue and placed on a small, mirrored platform for separation of nerve fibers. To prevent leakage of oil from the recording basin, a rubber-based polysulfide impression material (COE-FLEX, GC America Inc.) was applied externally around the ring to the skin of the hind limb and allowed to set for $\sim 20 \mathrm{~min}$ to form a hard seal. The epineurium of the tibial nerve was opened using a miniature scalpel, and small fascicles were cut to allow the proximal ends to be spread out on the platform for separation with fine jewelers forceps.

Nerve fascicles were teased apart, and fine filaments were placed on a silver-wire recording electrode maneuvered by a micromanipulator. Extracellular recordings were obtained only from single fibers that could be easily discriminated according to amplitude and shape. Action potentials were amplified, audio monitored, displayed on an oscilloscope, and stored on a VCR before being sent to a PC computer for data acquisition. Evoked responses were analyzed off-line using a customized data analysis program (LabVIEW, version 5.1). An amplitude window discriminator was used to separate action potentials of the fiber under study from those of other fibers and from background noise. However, recordings typically consisted of one afferent fiber.

Identification of primary afferent fibers. The receptive fields (RFs) of cutaneous afferent fibers were identified using mechanical stimuli. Mechanical stimulation proceeded by a graduated approach beginning with large and soft stimulation with a cotton swab or the experimenter's fingers, followed by mild pinching with curved serrated forceps. Once a fiber was isolated, the location of its RF was identified using a small glass probe (1 mm diameter) or a suprathreshold von Frey monofilament, or both. The RF location was then marked on the skin with a felt-tip pen and reconstructed on a drawing of the mouse hindpaw.

Conduction velocity. By electrical stimulation of the RF of each isolated fiber, the conduction latency and distance of action potentials between the RF and the recording electrode were determined for calculation of conduction velocity. Two fine needle electrodes ( 30 gauge) were inserted into the skin on opposite sides adjacent to the RF. Square-wave pulses (duration $0.2 \mathrm{msec}, 0.5 \mathrm{~Hz}$ ) were delivered at a stimulating voltage 1.5 times the voltage required to evoke a threshold response. Average conduction latencies were previously obtained from compound action potentials so that fibers with conduction velocities $\geq 1.3 \mathrm{~m} / \mathrm{sec}$ were classed as myelinated and subdivided into A $\delta$-fibers $(1.3-13.6 \mathrm{~m} / \mathrm{sec})$ and $\mathrm{A} \beta$-fibers $(>13.6 \mathrm{~m} / \mathrm{sec})$. Fibers with conduction velocities $<1.3 \mathrm{~m} / \mathrm{sec}$ were identified as $\mathrm{C}$-fibers.

Mechanical stimulation. To ensure that recordings were obtained exclusively from fibers innervating cutaneous RFs rather than from deeper units innervating muscle, the skin surrounding the RF was gently grasped with curved forceps and lifted. Only fibers that discharged primarily while the skin around the RF was lifted above the underlying tissue and lightly squeezed were considered to be cutaneous units. At the time of unit isolation, toes and joints were manipulated to identify proprioceptive units, which were not studied further. Individual fibers were classed according to general response properties, including conduction velocity, waveform, and response to gradations of various mechanical stimuli such as light stroking with cotton swab and applied pressure with a roundtipped glass rod. Mechanical thresholds were determined using calibrated von Frey monofilaments (Stoelting) and were expressed as the minimum force (in milliNewtons) needed to evoke a response in at least $50 \%$ of the trials. The range of von Frey filaments used in this study exerted bending forces from 0.1 to $177.5 \mathrm{mN}$. Low-threshold mechanoreceptors (A $\beta$ fibers) were identified as either rapidly adapting (RA) or slowly adapting (SA) by applying constant force using a suprathreshold von Frey monofilament ( $73 \mathrm{mN}$ bending force) that was secured to a microdrive and manually lowered onto the RF for $10 \mathrm{sec}$.

Thermal stimulation. Thermal stimuli were delivered by a Peltier-type thermode controlled by a customized software program. Heat stimuli ranging from 35 to $51^{\circ} \mathrm{C}$ were presented in ascending steps of $2^{\circ} \mathrm{C}$ from a base temperature of $32^{\circ} \mathrm{C}$. Each stimulus was applied for $5 \mathrm{sec}$ duration with an interstimulus interval of $60 \mathrm{sec}$. The rise and fall of each thermal stimulus presented was $20^{\circ} \mathrm{C} / \mathrm{sec}$. After a period of at least $5 \mathrm{~min}$, cold stimuli (each of $10 \mathrm{sec}$ duration) were presented in descending increments of $4^{\circ} \mathrm{C}$ from $28^{\circ} \mathrm{C}$ to $-12^{\circ} \mathrm{C}$ and were applied with a ramp rate of $5^{\circ} \mathrm{C} / \mathrm{sec}$. An interstimulus interval of $160 \mathrm{sec}$ occurred between each increment of cold stimulation.

The relatively large contact area of the thermode (contact area $1 \mathrm{~cm}^{2}$ ), which was attached to a manipulator, facilitated a firm contact with the $\mathrm{RF}$. For $\mathrm{A} \delta$ - and $\mathrm{C}$-units, the thermode was lowered onto the RF exerting 
pressure just sufficient to elicit a response, thus assuring the proper angle and position of the thermode over the RF. Then, the thermode was delicately adjusted (by manipulator) until the mechanically induced response ceased yet a visible indentation of the skin was maintained.

Fiber classification. The procedure used to classify mouse primary afferent fibers has been described previously (Cain et al., 2001). Briefly, mechanoreceptors were considered RA if they exhibited an abrupt response to the onset (and offset) of mechanical stimuli but failed to maintain discharge during the $10 \mathrm{sec}$ trial. SA mechanoreceptors were those that discharged throughout the $10 \mathrm{sec}$ period of stimulation.

Nociceptors were characterized according to responses evoked by noxious mechanical, heat, and cold stimuli. In the absence of a response to the applied range of thermal stimuli, $\mathrm{A} \delta$ and $\mathrm{C}$ nociceptors were classed as mechanonociceptors (AM and CM, respectively). Nociceptors excited by heat, but not cold, were classed as mechanoheat nociceptors $(\mathrm{AMH}, \mathrm{CMH})$, and those responding to cold but not heat were classed as mechanocold nociceptors (AMC, CMC). Nociceptors excited by both types of thermal stimuli, mechanoheat/mechanocold nociceptors, were designated $\mathrm{AMHC}$ or $\mathrm{CMHC}$. AMH nociceptors exhibiting response thresholds $\leq 51^{\circ} \mathrm{C}$ were subclassed as $\mathrm{AMH}$ type II fibers. Those A $\delta$ nociceptors not responsive during initial heat trials were exposed (up to three times) to $53^{\circ} \mathrm{C}$ for $30 \mathrm{sec}$ to induce sensitization to heat. If these nociceptors subsequently responded to heat, they were classified as AMH type I (Meyer et al., 1985; Treede et al., 1992).

\section{Studies of epidermal innervation}

Twenty-seven $\mathrm{C} 3 \mathrm{H}$ mice (11 control, 16 hyperalgesic mice with tumor) were used to identify possible effects of tumor growth on density and branching of epidermal nerve fibers (ENFs). After injection with pentobarbital $(60 \mathrm{mg} / \mathrm{kg}$, i.p.), a punch biopsy was obtained from the skin overlying the heel of the left hind paw and fixed in Zamboni's solution (2\% paraformaldehyde, $0.2 \%$ picric acid in PBS, $\mathrm{pH} 7.6$, for $24 \mathrm{hr}$ at $4^{\circ} \mathrm{C}$, then cryoprotected in $0.1 \mathrm{M}$ PBS, pH 7.4, containing $20 \%$ sucrose and stored at $4^{\circ} \mathrm{C}$ until further processing.

Biopsies were sectioned at $30 \mu \mathrm{m}$ and washed free-floating in PBS with $0.3 \%$ Triton X-100 and 5\% normal donkey serum (NDS) for $1 \mathrm{hr}$, then incubated in primary antisera overnight at $4^{\circ} \mathrm{C}$. Rabbit antisera to protein gene product (PGP) 9.5 (Ultraclone, Isle of Wight, UK) and goat antisera to type IV collagen (Southern Biotechnology Associates, Inc., Birmingham, AL) were used. All primary antibodies were diluted in PBS with $0.3 \%$ Triton X-100 and $1 \%$ NDS. The following day the sections were washed three times with the same diluting solution and incubated with donkey anti-rabbit antibodies conjugated to $\mathrm{Cy}-3$ and donkey antigoat antibodies conjugated to $\mathrm{Cy}-2$ (Jackson ImmunoResearch, West Grove, PA; $1: 200)$ overnight at $4^{\circ} \mathrm{C}$. After additional rinses in the diluting solution, sections were adhered to coverslips with $1 \%$ Nobel agar (Sigma, St. Louis, MO), dehydrated in ethanol, cleared in methyl-salicylate, and mounted on slides with DPX (Fluka, Buchs, Switzerland). Fluorescent samples were viewed with an epifluorescence-equipped Nikon Microphot-SA microscope using appropriate filters. Selected sections were imaged with a CARV non-laser Confocal Microscope System (ATTO Instruments, Rockville, MD). Images were collected in successive frames of $1 \mu \mathrm{m}$ serial optical sections (Z-series) through the thickness of the sections using a $40 \times$ oil Zeiss plan apochromat objective (numerical aperture 1.3). Each Z-series of images was either projected into a single in-focus image and printed with a Kodak ColorEase thermal dye diffusion printer or used as a Z-series for quantification of nerve fibers.

Quantitative analyses of ENFs were conducted as described previously (Kennedy et al., 1996). The number of ENFs and nodes per fiber in epidermal images was counted using a $40 \times$ objective with a Nikon Microphot-SA fluorescent microscope. Epidermal innervation was evaluated from Z-series stacks of PGP 9.5-immunostained ENFs, and the images were analyzed with Neurolucida software (MicroBrightfield, Colchester, VT) by tracing nerve fibers in three dimensions. Individual ENFs were counted after they passed through the basement membrane so that branching occurring within the epidermis did not increase the number of ENFs counted. Fiber counts per millimeter length of epidermis were standardized for section thickness $(25 \mu \mathrm{m})$ and expressed as the number of fibers per millimeter of epidermis.

\section{Data analyses}

Electrophysiology. Action potentials and discriminated spikes were stored on videotape and on a laboratory computer for off-line analysis. Thermal stimuli, including ascending and descending ramps and the time at which they were reached, were also digitized and stored. An additional channel stored a digitized trace of voltage from a footswitch used to identify the time of mechanical stimulation for characterization of rapidly and slowly adapting responses.

Differences in mechanical threshold among fiber types were determine using the Kruskal-Wallis ANOVA and Mann--Whitney $U$ tests. The responses of $\mathrm{A} \delta$ - and $\mathrm{C}$-fibers to thermal stimuli were analyzed on the basis of the number of impulses and the frequency, i.e., discharge rate (from first to last evoked impulse) evoked by each stimulus. The LabVIEW software files were reviewed for each thermal stimulus trial. To obtain the discharge frequency, the exact number of spikes was divided by the time difference between the first spike and the last spike in response to each thermal stimulus. The mean was computed from the discharge frequency totals obtained for each temperature stimulus for either $\mathrm{A} \delta$ - or $\mathrm{C}$-fibers. Frequency could not be calculated for responses consisting of a single impulse. Differences in response thresholds for heat and cold between fiber types were analyzed using a one-way ANOVA and Newman-Keuls post hoc comparisons. Responses of C-fibers evoked by suprathreshold heat stimuli were analyzed by within-and-betweensubjects ANOVA performed on the log of spikes +1 to homogenize variability.

Morphology. The Mann-Whitney rank sum test was used to assess whether the number of ENFs per millimeter length of epidermis and the branching (nodes per fiber) differed significantly. $\chi^{2}$ tests were used to determine the proportion of ENFs having no branching, one node per fiber, or two or more nodes per fiber. A probability of $<0.05$ was considered significant for statistical comparisons.

\section{RESULTS}

As shown in a related study in this issue (Wacnik et al., 2001), the fibrosarcoma tumor caused progressive destruction of the calcaneus bone. Hematoxylin and eosin staining showed that by postimplantation day 6 (PID 6) the edge of the calcaneus bone was irregular, and bone had deteriorated with tumor progression. Also, there was no indication that tumor cells invaded skin or nerve up to PID 12. Results showed a continuous progression in tumor diameter from day $3(4 \mathrm{~mm})$ to day $10(4.5 \mathrm{~mm})$, whereupon the rate increased and by day 15 heel width reached an average $5.5 \mathrm{~mm}$ (naive width $3.3 \mathrm{~mm}$ ) and maximal width of 8.2 $\mathrm{mm}$ in mice >PID 20 .

\section{Hyperalgesia in mice with tumors}

Sarcoma tumor cell implantation into the heel of $125 \mathrm{C} 3 \mathrm{H} / \mathrm{He}$ mice was associated with mechanical hyperalgesia beginning PID 7. Mechanical hyperalgesia was measured using a von Frey monofilament with a bending force of $3.8 \mathrm{mN}$ applied to the plantar surface of the hindpaw. The hyperalgesia developed with tumor growth from PID 6 through PID 15. In control mice, the frequency of withdrawal from the von Frey filament was 10-20\%, whereas the comparable values in tumor-bearing mice were $80-100 \%$.

\section{Responses of primary afferent fibers}

Recordings were obtained in the present study from a total of 190 primary afferent fibers, all of which were excited by mechanical stimuli applied to RFs located on glabrous skin. In control mice, 84 fibers were studied, of which 30 were identified as C-fibers, 21 as $\mathrm{A} \delta$-fibers, and 33 as $\mathrm{A} \beta$-fibers. Response properties were similar to those described in an earlier study of afferent fibers in the mouse tibial nerve (Cain et al., 2001). In addition, 106 fibers were isolated in mice with tumor, 50 were identified as $\mathrm{C}$-fibers, 26 as $\mathrm{A} \delta$-fibers, and 30 as $\mathrm{A} \beta$-fibers. All of the $\mathrm{C}$-fibers in mice with tumor were recorded at PID 8-17, except for one each at PID 19 and 20. Both $\mathrm{A} \delta$ - and $\mathrm{A} \beta$-fibers in mice with tumor were also evenly distributed between PID 8 and PID 17, and one $\mathrm{A} \beta$-fiber was recorded at PID 21. Fibers that were completely 


\begin{tabular}{|c|c|c|c|c|c|c|}
\hline \multirow{2}{*}{$\begin{array}{l}\text { Fiber } \\
\text { type }\end{array}$} & \multicolumn{2}{|c|}{ Number of fibers } & \multicolumn{2}{|c|}{ Mean $( \pm \mathrm{SE}) \mathrm{CV}(\mathrm{m} / \mathrm{sec})$} & \multicolumn{2}{|c|}{ Median mechanical threshold $(\mathrm{mN})$} \\
\hline & Control & Tumor & Control & Tumor & Control & Tumor \\
\hline $\mathrm{A} \beta$ & 33 & 30 & $20.8 \pm 1.2$ & $19.8 \pm 1.4$ & 4.4 & 1.2 \\
\hline RA & 23 & 24 & $19.5 \pm 1.5$ & $19.1 \pm 1.5$ & 2.1 & 1.2 \\
\hline SA & 10 & 6 & $23.9 \pm 1.8$ & $22.1 \pm 4.1$ & 6.1 & 2.8 \\
\hline $\mathrm{A} \delta$ & 21 & 26 & $6.2 \pm 0.6$ & $5.9 \pm 0.6$ & 10.3 & 5.2 \\
\hline $\mathrm{C}$ & 30 & 50 & $0.6 \pm 0.04$ & $0.5 \pm 0.03$ & 24.4 & 24.4 \\
\hline
\end{tabular}

\begin{tabular}{llclll} 
& \multicolumn{2}{c}{ Excited by heat } & & & \multicolumn{2}{c}{ Mean $\left( \pm\right.$ SEM) heat threshold $\left({ }^{\circ} \mathrm{C}\right)$} \\
\cline { 2 - 3 } & Control & Tumor & & Control & Tumor \\
\hline A $\delta$ & $2 / 16(12.5 \%)$ & $2 / 16(12.5 \%)$ & $49.0 \pm 0$ & $45.0 \pm 2.0$ \\
C & $17 / 27(63 \%)$ & $18 / 35(51 \%)$ & $41.8 \pm 1.0$ & $38.3 \pm 0.7$
\end{tabular}

\begin{tabular}{|c|c|c|c|c|}
\hline & \multicolumn{2}{|c|}{ Excited by cold } & \multicolumn{2}{|c|}{ Mean $( \pm$ SEM $)$ cold threshold $\left({ }^{\circ} \mathrm{C}\right)$} \\
\hline & Control & Tumor & Control & Tumor \\
\hline $\mathrm{A} \delta$ & $4 / 14(29 \%)$ & $5 / 14(36 \%)$ & $3.0 \pm 5.7$ & $11.2 \pm 6.1$ \\
\hline $\mathrm{C}$ & $34 / 44(77 \%)$ & $15 / 31(48 \%)$ & $10.2 \pm 2.6$ & $11.2 \pm 2.4$ \\
\hline
\end{tabular}

Functional subclassification of fibers according to temperature sensitivity ${ }^{a}$

\begin{tabular}{|c|c|c|c|c|c|}
\hline \multicolumn{3}{|c|}{ A $\delta$ fibers $(n)$} & & \multicolumn{2}{|c|}{ C fibers $(n)$} \\
\hline & Control & Tumor & & Control & Tumor \\
\hline $\mathrm{AM}$ & $67 \%(10)$ & $41 \%(7)$ & $\mathrm{CM}$ & $20 \%(5)$ & $24 \%(8)$ \\
\hline $\mathrm{AMC}$ & $20 \%(3)$ & $35 \%(6)$ & $\mathrm{CMC}$ & $16 \%(4)$ & $18 \%(6)$ \\
\hline AMH-I & $6.5 \%(1)$ & $12 \%(2)$ & $\mathrm{CMH}$ & $24 \%(6)$ & $30 \%(10)$ \\
\hline AMH-II & & $12 \%(2)$ & CMHC & $40 \%(10)$ & $21 \%(7)$ \\
\hline AMHC-I & $6.5 \%$ & & & & \\
\hline
\end{tabular}

${ }^{a}$ Only units tested for both heat and cold stimulus trials were classed.

tested with heat and cold stimulation paradigms were further grouped according to temperature sensitivity (Table 1).

\section{Spontaneous activity}

Unlike C-fibers in control mice in which none of the $30 \mathrm{C}$-fibers exhibited ongoing activity, $34 \%$ (17 of 50) of C-fibers in mice with tumor discharged action potentials spontaneously. Rates of spontaneous activity ranged from $\sim 0.2-3.4 \mathrm{~Hz}$ with a mean rate of 1.2 $\mathrm{Hz} \pm 0.24 \mathrm{~Hz}$. The peak discharge, the maximal rate of discharge of a fiber based on the shortest time interval between two action potentials, was $28.2 \mathrm{~Hz}$. Figure 1 illustrates the ongoing activity of three C-fibers (A, B, and C) accompanied (see below) by three superimposed traces verifying the constant response latency used to determine the conduction velocity of the fiber. Some C-fibers in mice with tumor displayed an intermittent bursting pattern of spontaneous activity (Fig. $1 C$ ).

The presence of spontaneous activity, in addition to being limited to $\mathrm{C}$-fibers in mice with tumor, increased with tumor progression. Logistic regression analysis indicated that ongoing activity, which was observed first in 33\% (1 of 3) of C-fibers at PID 9, peaked significantly at $83 \%$ (5 of 6) of the C-fibers recorded at PID $17(p<0.033)$. When the percentage of $\mathrm{C}$-fibers with spontaneous activity was calculated as a function of day after implantation, $82 \%$ (14 of 17) of such fibers were found to occur in the range of PID 13-17. Among later PID mice, electrophysiological responsiveness of all types of primary afferents in the nerve decreased sharply, thus making the isolation of single fibers difficult, and this physiological change coincided with the onset of the disappearance of ENFs as reported below (see Morphology of epidermal nerve fibers).

There was no obvious relationship between specific characteristics of the spontaneous activity and the functional class of C-fiber. Among the spontaneously active fibers, one was classed as $\mathrm{CM}$, one as $\mathrm{CMC}$, five as $\mathrm{CMH}$, and four as $\mathrm{CMHC}$. The functional classes of the other six spontaneously active C-fibers were not completely identified; however, all responded to mechanical stimuli.

The RFs of spontaneously active C-fibers were generally located in close proximity to the tumor, specifically, $88 \%$ (15 of 17) were on the plantar surface within $2 \mathrm{~mm}$ of the visible tumor periphery, whereas the RFs of two spontaneously active C-fibers were found on the toes $(\sim 3.5 \mathrm{~mm}$ from the edge of the tumor). No spontaneous activity was found between either $\mathrm{A} \beta$ - or $\mathrm{A} \delta$ fibers in this study.

\section{Responses evoked by thermal and mechanical stimuli}

Heat thresholds were determined for $18 \mathrm{C}$-fibers (from 18 mice with tumor) and 17 heat-sensitive $\mathrm{C}$-fibers (from 13 control mice). Thresholds of $\mathrm{C}$-fibers in mice with tumor were obtained from PID $8\left(n=2\right.$; mean $\left.39^{\circ} \mathrm{C}\right)$ to PID $17\left(n=1 ; 35^{\circ} \mathrm{C}\right)$. Although no correlation was found between heat threshold and PID, the mean response threshold of $\mathrm{C}$-fibers to heat was significantly $3.5^{\circ} \mathrm{C}$ lower $(p<0.01)$ in mice with tumor $\left(38.3^{\circ} \mathrm{C} \pm 0.7 ; n=18\right)$ relative to control mice $(41.8 \pm 1.0 ; n=17)$, as shown in Figure 2. In control mice, $41 \%$ ( 7 of 17 ) of the $\mathrm{C}$-fibers had response thresholds below $40^{\circ} \mathrm{C}$ compared with $78 \%$ (14 of 18) of the 


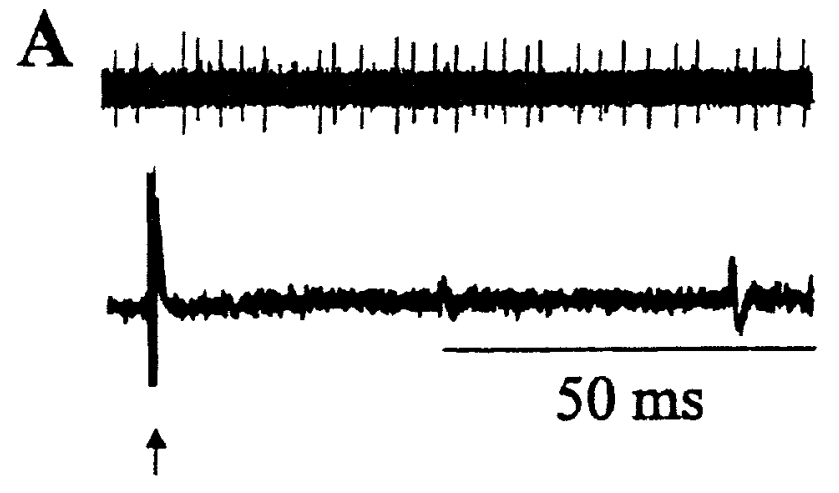

B
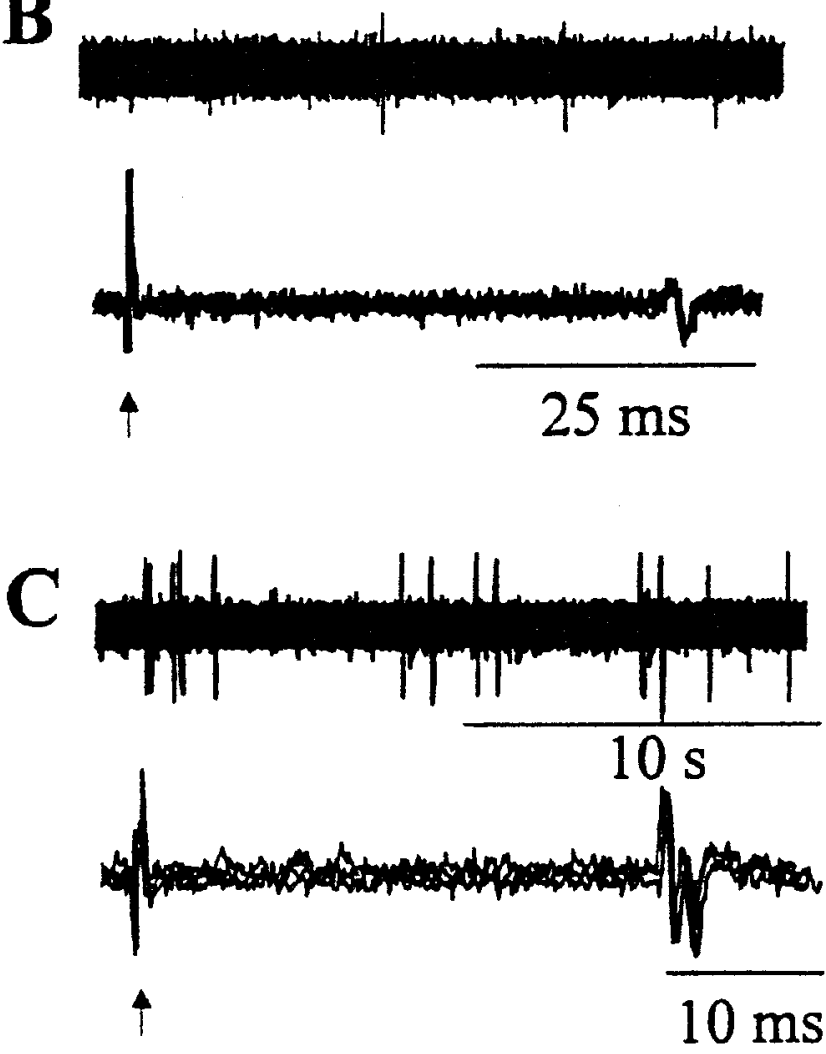

Figure 1. Representative examples of spontaneous activity and conduction latency of three $\mathrm{C}$-fibers recorded in skin overlying a fibrosarcoma tumor. $A$, Top, Spontaneous activity of this nociceptor occurred generally at a steady rate of $\sim 1 \mathrm{~Hz}$. A, Bottom, Three superimposed oscilloscope traces showing constant conduction latency evoked by electrical stimulation at the RF. $B$, A second C-fiber with a slower $(0.15 \mathrm{~Hz})$ rate of spontaneous activity. $C$, Spontaneous activity of this nociceptor occurred in bursts of three to five action potentials. Arrows indicate stimulus artifact. The $10 \mathrm{sec}$ calibration below the spontaneous activity in $C$ applies to all three traces of ongoing activity. Calibrations of individual conduction latencies are shown under the overlaid traces of constant conduction velocity.

$\mathrm{C}$-fibers in mice with tumor. In addition, responses of $\mathrm{C}$-fibers evoked by suprathreshold heat stimuli (Fig. $3 A$ ) were greater in mice with tumor than in control mice $(p<0.01)$, and the number of impulses between control and tumor for stimulus temperatures of $37-49^{\circ} \mathrm{C}$ showed a significant temperature-dependent difference $(p<0.01)$. Thus, sensitization to heat was manifested as a

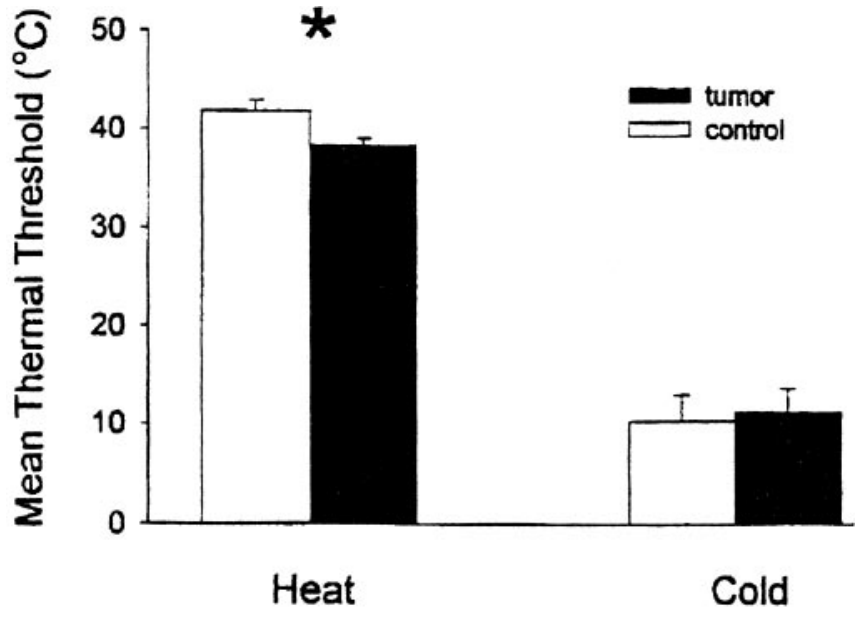

Figure 2. Mean $( \pm \mathrm{SE})$ response threshold for heat and cold in control (unfilled columns) and in mice with fibrosarcoma tumors ( filled columns). The mean heat threshold of $\mathrm{C}$-fibers in control mice was $41.8 \pm 1.09^{\circ} \mathrm{C}$ compared with $38.3 \pm 10.72^{\circ} \mathrm{C}$ in mice with tumor $(p=0.011)$. $*$ indicates a significant difference from control. The cold threshold of $\mathrm{C}$-fibers in mice with tumor was $11.2 \pm 2.4^{\circ} \mathrm{C}$ compared with $10.2 \pm 2.67^{\circ} \mathrm{C}$ in control mice.

decrease in response threshold and an increase in number of impulses evoked by suprathreshold heat stimuli. The histogram in Figure 4 differentiates between heat thresholds of nonspontaneously active and spontaneously active C-fibers in tumorbearing mice. Although the difference in heat thresholds between control and tumor mice was significant, no difference occurred between quiescent and spontaneously active $\mathrm{C}$-fibers in tumor mice. The ranges of response thresholds to heat for $\mathrm{C}$-fibers without and with spontaneous activity were $35-47$ and $35-39^{\circ} \mathrm{C}$, respectively.

In contrast, the mean cold threshold of $\mathrm{C}$-fibers in mice with tumors $\left(11.2^{\circ} \mathrm{C} \pm 2.4 ; n=15\right)$ compared closely with that of control mice $\left(10.2^{\circ} \mathrm{C} \pm 2.6 ; n=14\right)$, and no difference in mean response threshold was observed. Similarly, responses of C-fibers evoked by suprathreshold cold stimuli, illustrated in Figure $3 B$, did not differ significantly between control mice and tumorbearing mice. The histogram in Figure 4 further indicates that no significant difference in cold thresholds was observed between nonspontaneously active and spontaneously active C-fibers in mice with tumor. The range of response thresholds to cold was $24 \mathrm{C}^{\circ}$ to $-4 \mathrm{C}^{\circ}$ regardless of whether the $\mathrm{C}$-fiber was spontaneously active.

In tumor-bearing mice, two heat-sensitive $\mathrm{A} \delta$-fibers $(\mathrm{AMH}$ type II) had response thresholds of 47 and $43^{\circ} \mathrm{C}$, respectively. These response thresholds are similar to those observed in control mice (Table 1). In addition, the mean threshold of five cold-sensitive $\mathrm{A} \delta$-fibers (AMC) in mice with tumor was $11.2^{\circ} \mathrm{C} \pm$ 6.1 (range, -8 to $+28^{\circ} \mathrm{C}$ ) compared with a mean of $3.0 \pm 5.7^{\circ} \mathrm{C}$ from four cold-sensitive $\mathrm{A} \delta$-fibers in control mice. A larger sampling of responses of $A \delta$-fibers to cold reported in a previous study (Cain et al., 2001) found a mean cold threshold of $7.6 \pm$ $3.8^{\circ} \mathrm{C}$. Sensitivity of $\mathrm{A} \beta$-fibers to heat and cold was not tested.

No significant differences were observed for mechanical threshold of $\mathrm{C}$-fibers and $\mathrm{A} \delta$-fibers between control mice and tumorbearing mice. The median mechanical threshold of $\mathrm{C}$-fibers in control mice $(n=30)$ was $24.4 \mathrm{mN}$, and the median mechanical threshold of C-fibers in mice with tumor $(n=50)$ was also 24.4 


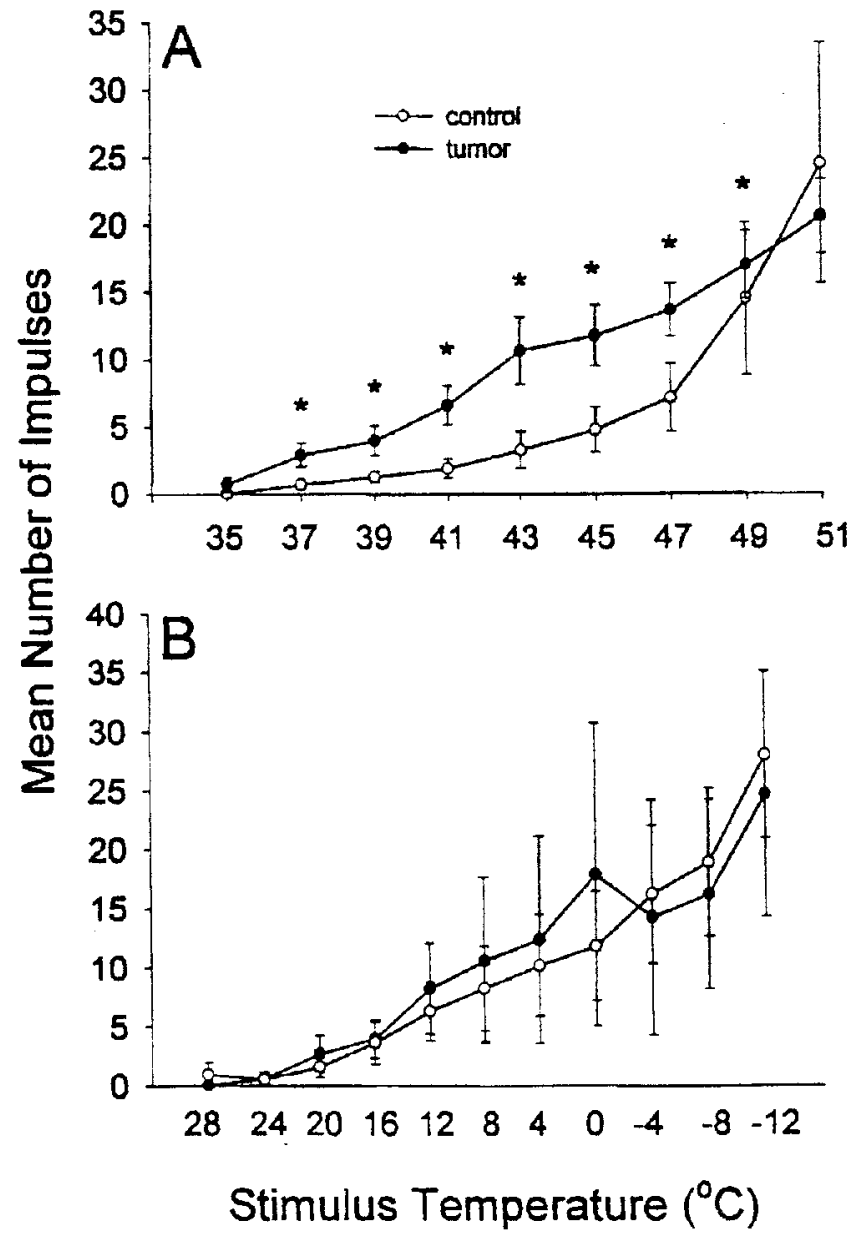

Figure 3. Stimulus response curves for $\mathrm{C}$-fibers in control mice $(\bigcirc)$ and mice with tumor $(\bullet)$ indicating mean $( \pm \mathrm{SE})$ number of impulses in response to thermal stimuli. $A, \mathrm{C}$-fibers discharged a greater number of impulses to heat stimuli $37-47^{\circ} \mathrm{C}$ in mice with tumor than in control mice. $B$, No significant difference was observed in C-fiber discharge to cold stimuli between control mice and mice with tumor.

$\mathrm{mN}$. The range of these thresholds was $1.2-177.5 \mathrm{mN}$ (control) and $2.1-111.5 \mathrm{mN}$ in mice with tumor. The median mechanical thresholds of $47 \mathrm{~A} \delta$-fibers (21 from control mice, 26 from mice with tumor) are stated in Table 1. For mice with tumor the median value was $5.2 \mathrm{mN}$ compared with $10.4 \mathrm{mN}$ in control mice; however, this difference was not significant. The median mechanical threshold of $\mathrm{A} \beta$-fibers in control mice was $4.4 \mathrm{mN}$ (range, 0.6-24.4 mN), which compared with a median of $1.18 \mathrm{mN}$ (range, $0.27-24.4 \mathrm{mN}$ ) in mice with tumor. This difference in median mechanical thresholds for $\mathrm{A} \beta$-fibers was significant $(p=0.01)$. Sensitivity of $\mathrm{A} \beta$-fibers to heat and cold was not tested.

Tibial nerve afferent fibers in mice with tumor underwent marked change in electrophysiological activity beyond 2 weeks of tumor growth. After PID 17 it became more difficult to record activity from individual primary afferents regardless of functional type, and by PID 20-24 fiber activity was rarely recorded. This decrease of afferent activity correlated with prodigious tumor growth as measured by a maximal heel width of $8.2 \mathrm{~mm}$ in mice $>$ PID 20 (compared with $3.3 \mathrm{~mm}$ in control) and was consistent with degeneration of cutaneous nerve fibers observed in later stages of tumor growth (see below).

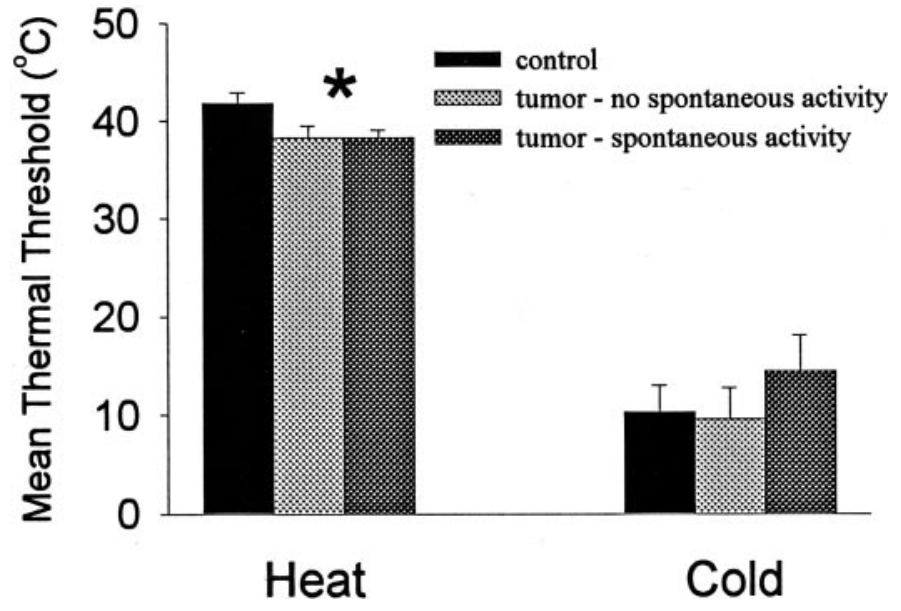

Figure 4. Mean $( \pm \mathrm{SE})$ thermal threshold in control mice (black) and nonspontaneously active and spontaneously active $\mathrm{C}$-fibers in mice with tumor. The asterisk (left columns) indicates a significant difference in mean heat thresholds between control and mice with tumor, but thresholds of C-fibers in tumor mice with spontaneous activity did not differ from those without it. Right columns, Neither the presence of tumor nor ongoing activity appeared to have an effect on cold thresholds of C-fibers.

\section{Morphology of epidermal nerve fibers}

The earliest biopsies from mice with tumor were obtained at PID 8 and the latest at PID 24. Confocal images of ENFs in skin biopsies are provided in Figure 5. These three representative images demonstrate the impact of tumor growth from normal (control) condition (left top) through PID 10 (left middle) to PID 24 (left bottom). The denervation of the epidermis is evident in the late stages of tumor progression, e.g., PID 24 coincided with a substantial attenuation of electrophysiological activity in the tibial nerve. The branching of ENFs, defined as the number of nodes or bif urcation points per fiber, was quantified by computerenhanced tracings of individual PGP 9.5 immunoreactive fibers from biopsied skin superficial to a tumor or from the same heel region in control mice. Figure $6 A$ indicates a significant increase in ENF branching in skin of mice with tumor, i.e., $0.27 \pm 0.02$ nodes per fiber compared with $0.13 \pm 0.02$ nodes per fiber in control mice $(p<0.007)$.

In addition to the observation of a greater number of branch points in ENFs of mice with tumors, analysis was also made of the proportion of fibers that had a specific number of nodes per fiber in each mouse group. Figure 7 illustrates the proportion of ENFs in control mice and mice with tumors having no branch points, one branch point, or two or more branch points. Control mice had a significantly higher proportion of ENFs having no branching (86 vs $75 \% ; p<0.01$ ), whereas the percentage of ENFs containing either one (13 vs $21 \% ; p<0.01)$ or two or more $(1.5$ vs $4 \% ; p<0.006)$ branch points was higher in mice with tumor (Fig. 7).

Conversely, the number of ENFs in mice with tumors declined with tumor growth. The most pronounced reduction of nerve fibers occurred in the epidermis after PID 16, and indeed some skin associated with extensive tumor growth ( $>$ PID 20) was completely devoid of intact fiber innervation in the epidermis. Figure $6 B$ indicates the significant change in the number of fibers per millimeter length of epidermis. Control mice exhibited a mean number of epidermal nerve fibers of $51.3 \pm 2.7$ compared with only $32.3 \pm 1.8$ fibers per millimeter length of epidermis in 

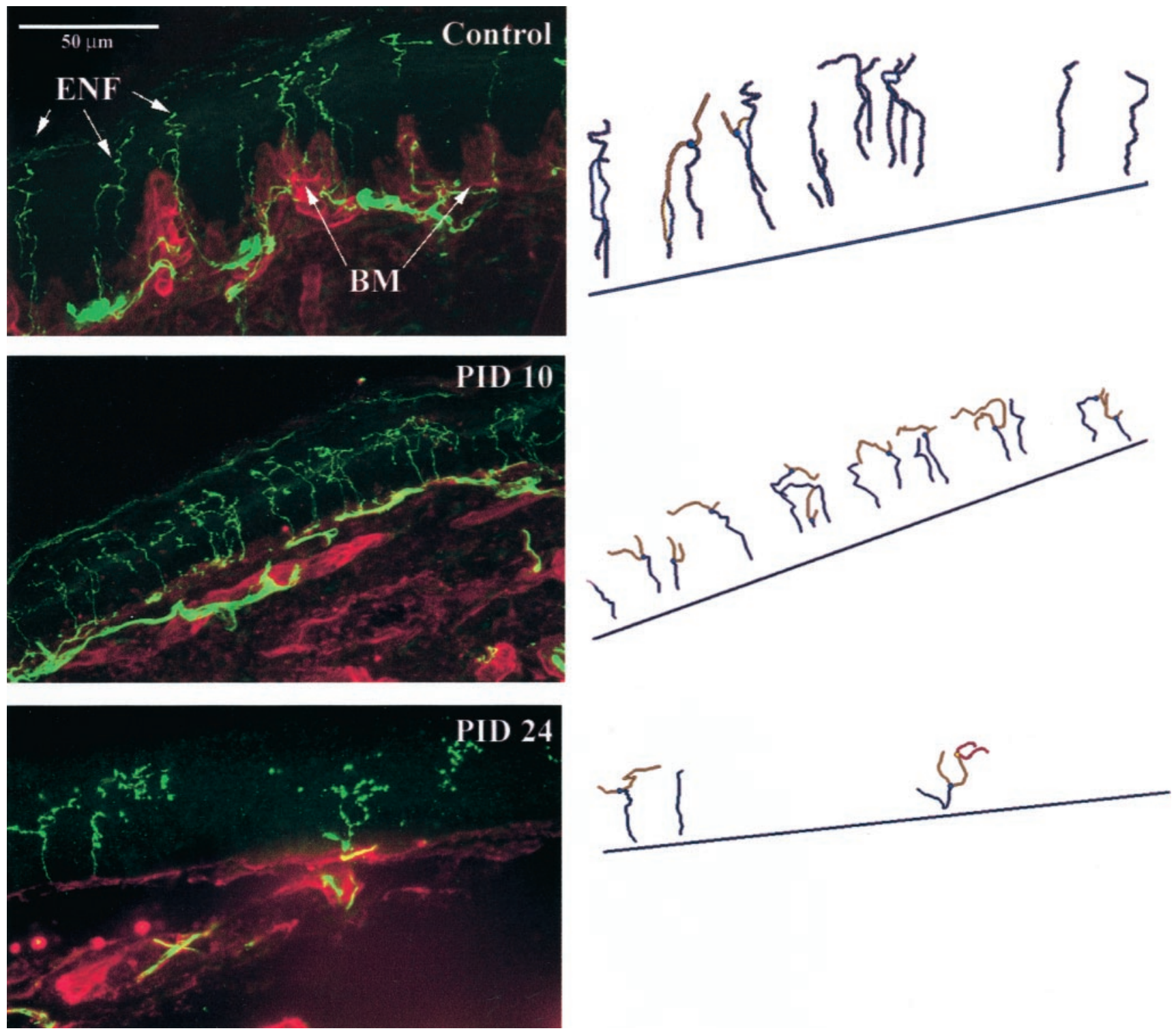

Figure 5. Effect of tumor growth on morphology of ENFs. Left panels, Confocal images of glabrous skin biopsies indicating ENFs ( green) and basement membrane (BM) and blood vessels (red) from a control mouse (top), a mouse with tumor $10 \mathrm{~d}$ after implantation of tumor-inducing cells (PID 10, middle), and a mouse with tumor $24 \mathrm{~d}$ after implantation (PID 24, bottom). ENFs in control mouse (top left) show normal innervation with relatively little branching. Within 2 weeks of implantation, increased fiber branching is evident (middle left). After $>3$ weeks of tumor progression, extensive atrophy results in loss of most ENFs. The scale bar applies to each of the panels. Right three panels, Neurolucida tracings corresponding to the composite image stack of ENFs on the corresponding left panels. Each image stack consists of a Z-series acquired in $1 \mathrm{~mm}$ increments throughout the thickness of the section. Note that the standard criterion for quantifying the number of fibers restricted tracings to continuous fibers passing through the basement membrane. Fiber fragments such as some of those seen in the bottom left image, for example, were not quantified. Straight lines approximating the basement membrane underneath ENF tracings (right panels) were used to determine the epidermal length of the image stack for calculation of number of fibers per millimeter of epidermis. Different branches of individual fibers are illustrated by different colors.

all tumor-bearing mice combined across times after implantation $(p<0.007)$.

\section{DISCUSSION}

Neuronal sensitization refers to an increase in excitability characterized by spontaneous activity, lowered response thresholds, and increased response to suprathreshold stimuli, all of which were observed in the present study. The most conspicuous difference in the responses of primary afferent fibers in tumor-bearing mice was the high incidence of spontaneous activity in C-fibers. Ongoing activity in unmyelinated and myelinated nociceptors has been associated with nerve injury (Meyer et al., 1985; Ali et al., 1999) or tissue inflammation (Kocher et al., 1987; Andrew and Greenspan, 1999). Clinical and experimental observations implicate spontaneous activity as a probable substrate of persistent neuropathic pain and progressive degenerative neuropathies (Gracely et al., 1992; Sheen and Chung, 1993). In addition, inflammatory pain may be evoked by the release of cytokines and growth factors (Woolf, 1996), thereby lowering nociceptor thresholds to the point at which body temperature and pressure of edema become adequate stimuli for excitation (Cesare and McNaughton, 1997; for review see, Sorkin and Wallace, 1999). Spon- 

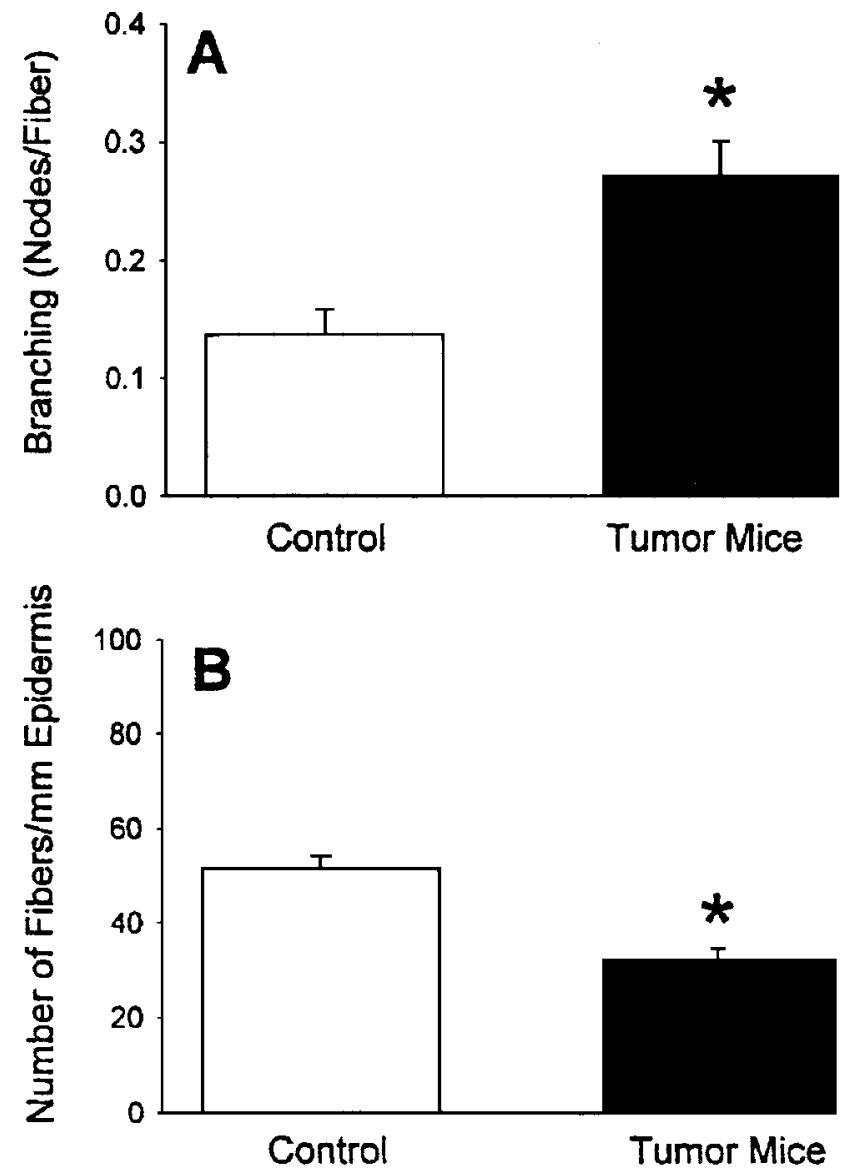

Figure 6. A, Effect of tumor growth on branching of ENFs and on epidermal innervation. Comparison of mean $( \pm \mathrm{SE})$ branching (nodes per fiber) observed in biopsy images from control mice ( 0.14 nodes per fiber \pm $0.02 ; n=60)$ and mice with tumor $(0.27 \pm 0.03 ; n=117)$. Significant difference is indicated by asterisk. $B$, The mean number of fibers per millimeter length of epidermis. The histogram shows a significant (asterisk) decline in the number of ENFs per millimeter of epidermis observed in biopsies from mice with tumor.

taneous activity may sustain central sensitization, which increases excitability of nociceptive spinal neurons (Cook et al., 1987; Willis, 1992; Woolf, 1992). That the spontaneous activity of $\mathrm{C}$-fibers observed in the present study may be maintaining central sensitization is consistent with the increased internalization of substance $\mathrm{P}$ receptors in the spinal cord of mice with bone cancer (Schwei et al., 1999; Honore et al., 2000a).

Interestingly, we found no spontaneous activity in myelinated fibers in tumor-bearing mice. Studies involving peripheral nerve injury in rats report ongoing activity in cutaneous myelinated fibers (Boucher et al., 2000; Liu et al., 2000) and in fibers innervating deep tissues (Proske et al., 1995; Michaelis et al., 2000). Recently it has been shown that spinal nerve injury evokes ectopic activity originating in the distal terminals of neighboring uninjured C-fibers (Wu et al., 2001). Patterns of spontaneous activity ranged from regular to bursting, similar to those in the present study.

Although we found that a proportion of $\mathrm{C}$-fibers in mice with tumor were sensitized to heat, this was not accompanied by a decrease in mechanical threshold. Earlier studies also found that inflammation or capsaicin lower heat, but not mechanical, thresholds of C-fibers (Reeh et al., 1986; Kocher et al., 1987; Baumann

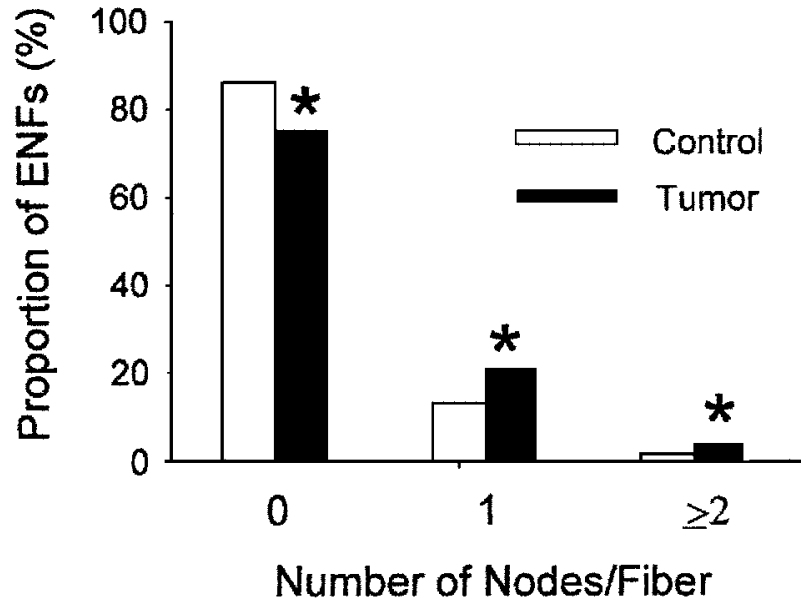

Figure 7. For control mice and mice with tumor, the proportions of ENFs having no branching, one node per fiber, or two or more nodes per fiber are compared. Fibers having no branching were significantly more abundant in control mice. Conversely, ENFs exhibiting one or more than or equal to two branch points were significantly more prevalent in mice with tumor. Asterisks indicate significant differences among groups.

et al., 1991). Recently, however, sensitization of cutaneous nociceptors to mechanical stimulation after inflammation was documented using suprathreshold mechanical stimuli (Andrew and Greenspan, 1999). In the present study, responses of nociceptors to mechanical stimuli that were above response threshold were not evaluated. We therefore cannot be certain whether mechanical hyperalgesia in this model is mediated primarily by nociceptor sensitization or by other mechanisms such as the sensitization of second-order sensory neurons in the spinal cord, i.e., central sensitization.

The observed decrease of mechanical thresholds for $\mathrm{A} \beta$-fibers in mice with tumor may be attributable to stretching of the skin or to changes in compliance of the skin that accompanied tumor growth. By PID 24 the maximal size of the heel tumor width measured $8.2 \mathrm{~mm}$ compared with $3.3 \mathrm{~mm}$ in control animals. Thus threshold changes of mechanoreceptors might have been induced indirectly by changes in the mechanical properties of the skin. However, the lowered thresholds of mechanoreceptors might contribute to mechanical hyperalgesia if their activity impinged on sensitized nociceptive dorsal horn neurons.

The mechanisms underlying the spontaneous activity and sensitization of $\mathrm{C}$-fibers in the present model are unknown. Excitability of nociceptors can be altered by such well known algogens as prostaglandins, bradykinin, histamine, certain cytokines, and trophic factors (for review, see Wacnik et al., 2000). The companion paper (Wacnik et al., 2001) reports elevated release from the tumor of the peptide ET-1. This finding is of interest because previous studies have implicated ET-1 in the transmission of nociceptive information in both animals and humans (Raffa et al., 1991, 1996a,b; Davar et al., 1998; Fareed et al., 2000; Piovezan et al., 2000; Pomonis et al., 2001). In addition, it is secreted in high concentrations by metastatic prostate and breast cancer cells (for review, see Gokin et al., 2001). Levels of ET-1 are also elevated in plasma of men with prostate cancer (Nelson et al., 1995). Administration of an ET-A receptor antagonist reduces cancer pain (Carducci et al., 1998) and decreases hyperalgesia in mice with this tumor (Wacnik et al., 2001). This evidence suggests that ET-1 may contribute to the tumor-evoked spontaneous activity. 


\section{Changes in nerve structure and innervation of the epidermis}

The most striking morphological effect of tumor growth encountered in this study was the progressive atrophy of ENFs, as indicated by a loss of immunoreactivity for PGP 9.5, which was measurable 2 weeks after implantation of cancer cells. ENFs are unmyelinated endings that are sensitive to the neurotoxic effect of capsaicin and have been shown to include nociceptors (Simone et al., 1998; Nolano et al., 1999). A particularly interesting finding was that mice exhibited mechanical hyperalgesia at a time when there was significant loss of epidermal innervation. The implication that denervation may be associated with pain and hyperalgesia is in agreement with several recent clinical studies. It has been shown that cutaneous innervation is reduced in several painful sensory neuropathies (Holland et al., 1997), including diabetes (Levy et al., 1992), human immunodeficiency virus (McCarthy et al., 1995), painful burning feet (Periquet et al., 1999), Fabry disease (Scott et al., 1999), and most recently, in postherpetic neuralgia (Oaklander et al., 1998; Oaklander, 2001). Oaklander (2001) has discussed possible explanations for the paradox that a decrease in the number of neurons, up to a point, may enhance rather than diminish nociceptive input. Developments in cancer mice observed in our study, i.e., the presence of ongoing C-fiber activity, increased number of impulses, and lowered response thresholds to heat stimuli, accompanied ENF degeneration near the tumor site of hyperalgesic mice $>2$ weeks after implantation. These changes in response to tissue injury may facilitate increased activation of second-order sensory neurons simultaneous to denervation of the skin and thus account for the hyperalgesia observed during advanced tumor progression. The loss of ENFs observed in cancer mice provides direct evidence that this model of cancer pain has a neuropathic component, at least in later stages. The persistent hyperalgesia observed despite a reduction in ENFs may be a manifestation of the functional redundancy inherent in nervous systems, whereby near-normal function can be preserved after neuron injury as long as a certain minimum number of neurons survive.

A second morphological feature that occurred after tumor growth was increased branching of ENFs, which represent axonal sprouting at the nociceptive ending. Several studies have considered the effects of axonal branching on action potential propagation, and the general conclusion is that action potentials generated in one branch may propagate antidromically into other branches and collide with action potentials generated there, leading to an occlusion of the action potential signal (Grossman et al., 1973; Stockbridge, 1988; Stockbridge and Stockbridge, 1988; Peng et al., 1999). Although the functional significance of increased branching of ENFs is unclear, one possibility is that an increase in branching of nociceptive terminals may add density to the sensory surface area through proliferation of transduction channels and/or elevated availability of endogenous compounds, such as nerve growth factor, involved in modulating excitability of nociceptors. Stucky et al. (1999) showed that mice overexpressing nerve growth factor in skin have a $50 \%$ increase in unmyelinated nociceptors in the saphenous nerve and a substantial increase in the percentage of C-fibers responsive to heat. This may account in part for spontaneous activity and sensitization of $\mathrm{C}$-fiber nociceptors.

Alternatively, the spontaneous activity coupled with the degenerative changes in ENFs observed in mice with tumor seems to be consistent with the Wallerian degeneration hypothesis. This hy- pothesis was proposed to account for spontaneous activity of uninjured $\mathrm{C}$-fibers commingling in the sciatic nerve with injured fibers degenerating as a result of spinal nerve injury (Wu et al., 2001). Nerve injury produced by spinal nerve ligation or transection may elicit release of substances such as nerve growth factor from injured fibers that could be transported back to the dorsal root ganglion where novel expression of receptor proteins could result in increased excitability.

\section{Conclusions}

A major impediment to understanding mechanisms underlying cancer pain has been the lack of appropriate animal models. New murine models of cancer pain are elucidating changes in biochemical, cellular, and physiological responses involved in the generation and maintenance of cancer pain. We show that tumor growth produces physiological and morphological alterations in primary afferent fibers that are characterized by spontaneous activity, sensitization of C-fiber nociceptors, and proliferation and subsequent degeneration of ENFs. These findings suggest that the observed behavioral hyperalgesia is mediated in part by sensitization of C-fibers. Furthermore, it is likely that central sensitization also occurs and may be maintained by spontaneous activity of C-fibers. An understanding of the functional interactions between tumors and peripheral nerves, and the consequences that those interactions have on the CNS, may identify novel targets for development of new therapies for cancer pain.

\section{REFERENCES}

Ali Z, Ringkamp M, Hartke TV, Chien HF, Flavahan NA, Campbell JN, Meyer RA (1999) Uninjured C-fiber nociceptors develop spontaneous activity and alpha-adrenergic sensitivity following L6 spinal nerve ligation in monkey. J Neurophysiol 81:455-466.

Allen BJ, Rogers SD, Ghilardi JR, Menning PM, Kuskowski MA, Basbaum AI, Simone DA, Mantyh PW (1997) Noxious cutaneous therma stimuli induce a graded release of endogenous substance $\mathrm{P}$ in the spinal cord: imaging peptide action in vivo. J Neurosci 17:5921-5927.

Allen BJ, Li J, Menning PM, Rogers SD, Ghilardi J, Mantyh PW, Simone DA (1999) Primary afferent fibers that contribute to increased substance $\mathrm{P}$ receptor internalization in the spinal cord after injury. J Neurophysiol 81:1379-1390.

Andrew D, Greenspan JD (1999) Mechanical and heat sensitization of cutaneous nociceptors after peripheral inflammation in the rat. J Neurophysiol 82:2649-2656.

Baumann TK, Simone DA, Shain CN, Lamotte RH (1991) Neurogenic hyperalgesia: the search for the primary cutaneous afferent fibers that contribute to capsaicin-induced pain and hyperalgesia. J Neurophysiol 66:212-227.

Bonetti B, Panzeri L, Carner M, Zamboni G, Rizzuto N, Moretto G (1997) Human neoplastic Schwann cells: changes in the expression of neurotrophins and their low-affinity receptor p75. Neuropathol Appl Neurobiol 23:380-386.

Boucher TJ, Okuse K, Bennett DL, Munson JB, Wood JN, McMahon SB (2000) Potent analgesic effects of GDNF in neuropathic pain states. Science 290:124-127.

Cain DM, Khasabov SG, Simone DA (2001) Response properties of mechanoreceptors and nociceptors in mouse glabrous skin: an in vivo study. J Neurophysiol 85:1561-1574.

Carducci M, Bowling M, Rogers T, Leahy T, Janus T, Padley R, Nelson J (1998) Endothelin receptor antagonist, ABT-627, for prostate cancer: initial trial results. In: American Association for Cancer Research Meeting, C-24, Indian Wells, CA, August.

Cesare P, McNaughton P (1997) Peripheral pain mechanisms. Curr Opin Neurobiol 7:493-499.

Clohisy DR, Ramnaraine ML (1998) Osteoclasts are required for bone tumors to grow and destroy bone. J Orthop Res 16:660-666.

Clohisy DR, Olgilvie CM, Carpenter RJ, Ramnaraine ML (1996) Localized tumor-associated ostolysis involves the recruitment and activation of osteoclasts. J Orthopaed Res 14:2-6.

Cook AJ, Woolf CJ, Wall PD, McMahon SB (1987) Dynamic receptive field plasticity in rat spinal cord dorsal horn following C-primary afferent input. Nature 325:151-153.

Davar G, Hans G, Fareed MU, Sinnott C, Strichartz G (1998) Behavioral signs of acute pain produced by application of endothelin-1 to rat sciatic nerve. NeuroReport 9:2279-2283.

Fareed MU, Hans GH, Atanda A, Strichartz G, Davar G (2000) Phar- 
macological characterization of acute pain behavior produced by application of endothelin-1 to rat sciatic nerve. J Pain 1:46-53.

Gokin AP, Fareed MU, Pan H-L, Hans G, Strichartz GR, Davar G (2001) Local injection of endothelin-1 produces pain-like behavior and excitation of nociceptors in rats. J Neurosci 21:5358-5366.

Gracely RH, Lynch SA, Bennett GJ (1992) Painful neuropathy: altered central processing maintained dynamically by peripheral input. Pain 51:175-194.

Grossman Y, Spira ME, Parnas I (1973) Differential flow of information into branches of a single axon. Brain Res 64:379-386.

Holland NR, Stocks A, Hauer P (1997) Intraepidermal nerve fiber density in patients with painful sensory neuropathy. Neurology 48:708-711.

Honore P, Rogers SD, Schwei MJ, Salak-Johnson JL, Luger NM, Sabino MC, Clohisy DR, Mantyh PW (2000a) ) Murine models of inflammatory, neuropathic and cancer pain each generate a unique set of neurochemical changes in the spinal cord and sensory neurons. Neuroscience 98:585-598.

Honore P, Luger NM, Sabino MAC, Schwei MJ, Rogers SD, Mach DB, O'Keefe PF, Ramnaraine ML, Clohisy DR, Mantyh PW (2000b) Osteoprotegerin blocks bone cancer-induced skeletal destruction, skeletal pain and pain-related neurochemical reorganization of the spinal cord. Nat Med 6:521-528.

Kocher L, Anton F, Reeh PW, Handwerker HO (1987) The effect of carrageenan-induced inflammation of the sensitivity of unmyelinated skin nociceptors in the rat. Pain 29:363-373.

Levy DM, Terenghi G, Gu XH (1992) Immunohistochemical measurement of nerves and neuropeptides in diabetic skin: relationship of tests of neurological function. Diabetologia 35:889-897.

Liu CN, Wall PD, Ben Dor E, Michaelis M, Amir R, Devor M (2000) Tactile allodynia in the absence of $\mathrm{C}$-fiber activation: altered firing properties of DRG neurons following spinal nerve injury. Pain 85:503-521.

Mantyh PW, Allen CJ, Ghilardi JR, Rogers SD, Mantyh CR, Liu H, Basbaum AI, Vigna SR, Maggio JE (1995) Rapid endocytosis of a G protein-coupled receptor: substance $\mathrm{P}$ evoked internalization of its receptor in the rat striatum in vivo. Proc Natl Acad Sci USA 92:2622-2626.

McCarthy BG, Hsieh S-T, Stocks A (1995) Cutaneous innervation in sensory neuropathies: evaluation by skin biopsy. Neurology 45:1848-1855.

Meyer RA, Raja SN, Campbell JN, Mackinnon SE, Dellon AL (1985) Neural activity originating from a neuroma in the baboon. Brain Res 325:255-260

Michaelis M, Liu X, Jänig W (2000) Axotomized and intact muscle afferents but not skin afferents develop ongoing discharges of dorsal root ganglion origin after peripheral nerve lesion. J Neurosci 20:2742-2748.

Nelson JB, Hedican SP, George DJ, Reddi AH, Piantadosi S, Eisenberger MA, Simons JW (1995) Identification of endothelin-1 in the pathophysiology of metastatic adenocarcinoma of the prostate. Nat Med 1:944-949.

Nolano M, Simone DA, Wendelschafer-Crabb G, Johnson T, Hazen E, Kennedy WR (1999) Topical capsaicin in humans: parallel loss of epidermal nerve fibers and pain sensation. Pain 81:135-145.

Oaklander AL (2001) the density of remaining nerve endings in human skin with and without postherpetic neuralgia after shingles. Pain 92:139-145.

Oaklander AL, Romans K, Horasek S, Stocks A, Hauer P, Meyer RA (1998) Unilateral posherpetic neuralgia is associated with bilateral sensory neuron damage. Ann Neurol 44:789-795.

Peng YB, Ringkamp M, Campbell JN, Meyer RA (1999) Electrophysiological assessment of the cutaneous arborization of A $\delta$-fiber nociceptors. J Neurophysiol 82:1164-1177.

Periquet MI, Novak V, Collins MP, Nagaraja HN, Erdem S, Nash SM, Freimer ML, Sahenk Z, Kissel JT, Mendell JR (1999) Painful sensory neuropathy: prospective evaluation using skin biopsy. Neurology 53:1641-1647.

Piovezan AP, D’Orleans-Just P, Souza GE, Rae GA, Tonussi CR (2000) Endothelin-1-induced ET(A) receptor-mediated nociception, hyperal- gesia and oedema in the mouse hind-paw: modulation by simultaneous ET(B) receptor activation. Br J Pharmacol 2000 129:961-968.

Pomonis JD, Rogers SD, Peters CM, Ghilardi JR, Mantyh PW (2001) Expression and localization of endothelin receptors: implications for the involvement of peripheral glia in nociception. 21:999-1006.

Proske U, Iggo A, Luff AR (1995) Mechanical sensitivity of regenerating myelinated skin and muscle afferents in the cat. Exp Brain Res 104:89-98.

Raffa RB, Schupsky JJ, Marinez RP, Jacoby HI (1991) Endothelin-1induced nociception. Life Sci 49:L61-L65.

Raffa RB, Schupsky JJ, Jacoby HI (1996a) Endothelin-induced nociception in mice: mediation by ETA and ETB receptors. J Pharmacol Exp Ther 276:647-651.

Raffa RB, Schupsky JJ, Lee DK, Jacoby HI (1996b) Characterization of endothelin-induced nociception in mice: evidence for a mechanistically distinct analgesic model. J Pharmacol Exp Ther 278:1-7.

Reeh PW, Kocher L, Jung S (1986) Does neurogenic inflammation alter the sensitivity of unmyelinated nociceptors in the rat. Brain Res $384: 42-50$.

Schwei MJ, Honore P, Rogers SD, Salak-Johnson JL, Finke M, Ramaraine ML, Clohisy DR, Mantyh PW (1999) Neurochemical and cellular reorganization of the spinal cord in a murine model of bone cancer pain. J Neurosci 19:10886-10897.

Scott LJC, Griffin JW, Luciano C, Barton NW, Banerjee T, Crawford T, McArthur JC, Tournay A, Schiffmann R (1999) Quantitative analysis of epidermal innervation in Fabry disease. Neurology 52:1249-1254.

Sheen K, Chung JM (1993) Signs of neuropathic pain depend on signals from injured nerve fibers in a rat model. Brain Res 610:62-68.

Simone DA, Nolano M, Wendelschafter-Crabb G, Kennedy WR (1998) Intradermal injection of capsaicin in humans produces degeneration and subsequent reinnervation of epidermal nerve fibers: correlation with sensory function. J Neurosci 18:8947-8959.

Sorkin LS, Wallace MS (1999) Acute pain mechanisms. Surg Clin North Am 79:213-229.

Stockbridge N (1988) Differential conduction at axonal bifurcations. II. Theoretical basis. J Neurophysiol 59:1286-1295.

Stockbridge N, Stockbridge LL (1988) Differential conduction at axonal bifurcations. I. Effect of electrotonic length. J Neurophysiol 59:1277-1285.

Stucky CL, Koltzenburg M, Schneider M, Engle MG, Albers KM, Davis BM (1999) Overexpression of nerve growth factor in skin selectively affects the survival and functional properties of nociceptors. J Neurosci 19:8509-8516.

Treede RD, Meyer RA, Raja SN, Campbell JN (1992) Peripheral and central mechanisms of cutaneous hyperalgesia. Prog Neurobiol 38:397421.

Tsujino K, Yamate J, Tsukamoto Y, Kumagai D, Kannan Y, Jippo T, Kuwamura M, Kotani T, Takeya M, Sakuma S (1997) Establishment and characterization of cell lines derived from a transplantable rat malignant meningioma: morphological heterogeneity and production of nerve growth factor. Acta Neuropathol 93:461-470.

Wacnik PW, Wilcox GL, Clohisy DR, Ramnaraine ML, Eikmeier LJ, Beitz AJ (2000) Cancer pain mechanisms and animal models of cancer pain. Proceedings of the 9th World Congress on Pain (Devor M Rowbotham M, Wiesenfeld-Hallin Z, eds) pp 1-23. Seattle: IASP.

Wacnik PW, Eikmeier LJ, Ruggles TR, Ramnaraine ML, Walcheck BK, Beitz AJ, Wilcox GL (2001) Functional interactions between tumor and peripheral nerve: morphology, algogen identification, and behavioral characterization of a new murine model of cancer pain. J Neurosci 21:9355-9366.

Willis WD (1992) Hyperalgesia and allodynia. New York: Raven.

Woolf CJ (1992) Excitability changes in central neurons following peripheral damage. In: Hyperalgesia and allodynia (Willis WD, ed), pp 221-243. New York: Raven.

Woolf CJ (1996) Phenotypic modification of primary sensory neurons: the role of nerve growth factor in the production of persistent pain. Philos Trans R Soc Lond B Biol Sci 351:441-448.

Wu G, Ringkamp M, Hartke TV, Murinson BB, Campbell JN, Griffin JW, Meyer RA (2001) Early onset of spontaneous activity in uninjured $\mathrm{C}$-fiber nociceptors after injury to neighboring nerve fibers. J Neurosci 21:RC137(1-5). 